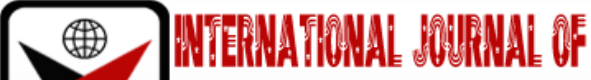

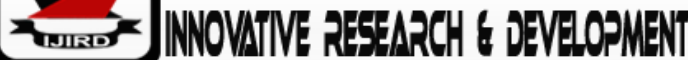

ISSN 2278-0211 (Online)

\section{Teachers' Pedagogical Content Knowledge on Drawing in the Acquisition of Communication Skills in Early Years Education in Kenya}

\author{
Tonui, Betty Chepng'etich \\ Lecturer, Department of CIEM, School of Education, Moi University, Kenya \\ Chang'ach, John \\ Dean, School of Education, Moi University, Kenya
}

\begin{abstract}
:
Studies globally and regionally indicate a low reading and communication attainment by children, with $90 \%$ of them in $3^{\text {rd }}$ world countries not attaining the average levels required. The majority across Africa struggle to read and communicate, which leads to meagre academic performance, Kenya is no exception to this trend. This scenario has been associated partly with challenges related to communication skills acquisition. Therefore, how teachers' aid learners to obtain the ability to converse is a question in this study. This study sought to explore Teachers' pedagogical content knowledge of drawing; The study was guided by Piaget's Cognitive theory. The study adopted a pragmatic philosophical approach which allows for a mixed method research design. The study's population comprised of 6 ECDE sub-county EYE program officers, 1201 EYE schools and EYE teachers and 53,276 PP2 class learners in Nandi County. The study stratified Nandi County into six sub-counties and used Yamane formula to arrive at the sample of schools. 300 teachers, one per school was purposely sampled out and 15 teachers were selected through convenience sampling for the interviews. Non-Proportionate purposive sampling was used to pick the drawings from the pupils. A census of 6 EYE program officers was picked as respondents. The research instruments used in this study were questionnaires, interview schedules and document analysis. A mixed approach research design was used whereby quantitative data were analyzed using descriptive and inferential statistics while qualitative data were analyzed using themes. The study found that there is a significant positive relationship between the teachers' pedagogical content knowledge on drawing and use in the acquisition of communication skills in Early years education $(\beta 1=0.206, p<0.05)$. This was supported by views of the teachers and program officers who were interviewed and documents analyzed. The study concluded that the majority of EYE teachers are not adequately prepared with content knowledge on drawing and that drawing is an effective tool in Early Years Education and teachers can utilize it to assist learners acquire their communication skills. Therefore, the study recommends refresher courses and further training, especially on the Early Years Education curriculum design, to improve the teachers' pedagogy in drawing.
\end{abstract}

Keywords:Teachers content knowledge, drawing, acquisition, communication skills

\section{Introduction}

Global and regional studies including; U.S.A, Britain, New Zealand, Nigeria, Rwanda, Malawi and Uganda indicate a low reading and communication achievement by children with $90 \%$ of children in 3rd world countries unable to read a basic book making them not reach the average levels required. More than half of 10 years old children in 135 countries cannot read a text and are struggling to read, leading to poor academic performance (World Bank, 2013 \& UNESCO 2014, June 2020, SSRN Electronic journal). Kenya is no exception to this trend. This scenario has been associated partly with challenges related to early years Communication skill inadequacies. This therefore requires EYE interventions to the social and economic progress of any country as they provide children aged between 4 and 5 with a robust foundation in life. Children who access EYE services will be more likely to register in primary schools at the correct age and less likely to drop out of school or repeat grades (Republic of Kenya, 2012). This study sought to explore the teacher's pedagogical content knowledge in the acquisition of communication skills in Early Years Education in Nandi County, Kenya.

Communication is particularly significant for interactions, social relationships and building a sense of belonging in EYE as reiterated by Jwan (2017). He further notes that the most outstanding accomplishment of the Pre-school years are the learners' development of communication skills. Communication is a two-way sharing of information that helps to develop a common understanding and meaning between the communicators (Schiavio\&Hфffding, 2015). As learners enter schooling, they are to use acquired communication skill as a tool for learning and social negotiation. The significant role of communication in school-aged children's lives suggests that individual variances in these skills may entail benefits and perils, in terms of broader academic and psycho-social capability (Gilbert, Spears \& Mistry, 2017). As observed by Brice (2012) Communication is very critical to a child's development. He sees the ability to communicate as a prerequisite to 
effective learning among school learners. Many learners experience communication challenges that interfere with their ability to learn effectively. Hence, teachers need strategies to use to help learners acquire communication skills. This study investigates teacher's pedagogical content knowledge on drawing in the acquisition of communication skills in EYE.

Communication occurs both verbally and non-verbal (Dequara, 2015). This is supported by Vince (2016) that Communication is spoken conversations (for example person to person) and written messages for example letters, electronic mail, bulletins) while Non-verbal communication is less direct. This study sought to explore the teachers' pedagogical content knowledge on drawing in acquisition of communication skills in EYE. A teacher can usually listen and observe this from the learners' body language (for example, crying or speaking) and tone of voice (Brice, 2012). In many instances in early years settings, teachers depend more on non-verbal communication than words to convey and receive meaning. This is especially so when learners are trying to communicate complex feelings, ideas and concepts, as nonverbal communication aids to convey meaning and understanding throughout a dialogue (Metin\& Aral, 2020). They further noted that, non-verbal communication can indicate a willingness to participate in a discussion and can help create pathways for communication between learners and teachers. Teachers therefore have a part in setting up opportunities for learners to acquire a language of communication both directly through interaction with the learners and indirectly by creating an environment that is rich in learning stimuli. This study believes that, this can be done by encouraging prompt discussion and reflection of their own ideas to promote verbalization to encourage originality and independence of expression.

This study believes that there is a lack of clear evidence on whether teachers have adequate pedagogical knowledge on drawing for use in helping the young learners acquire the communication competency skills. This study therefore, attempts to address these concerns whether EYE teachers have been trained on drawing pedagogy and can use that content knowledge as a tool in the acquisition of communication skills in EYE.

\subsection{Objective of the Study}

To explore the teacher's pedagogical content knowledge on drawing in the acquisition of communication skills in Early Years Education.

\subsection{Research Hypothesis}

The following hypotheses were tested;

- $\mathrm{H}_{01}$ : Teacher's pedagogical content knowledge on drawing has no significant influence on the acquisition of communication skills in Early Years Education.

\subsection{Theoretical Framework for the Study}

This study was guided by Piagets Cognitive theory. His ideas are relevant to this study and inform the theoretical framework.Piaget's cognitive theory suggests that, learning is a continuous process and knowledge being a fluid construct of one's 'psychology' that grows as one experiences more things and learns new concepts. This means that knowledge begets more knowledge. The theory promotes the active inclusion of learners into the learning process as a means to improving their learning outcomes which includes communication skill acquisition. Piaget argued that children are masters of their own learning experience and they develop healthy mental models that allow them to construct new knowledge from their understanding of their environment. Piaget suggested that learning in children could be more effective and sustainable if teachers plan for them activities as well as environment and then left to explore their environments freely. Their curiosity leads to creative cognitive abilities being expressed. As a result, they can grasp the concepts of reading and writing (drawing) through the problem-solving methods they develop for and by themselves. Therefore, Piaget argues that the teachers contribute to knowledge that is presented to children to explore is in itself only a means to an end and not an end in itself. This is because writing (drawing) is only part of the knowledge development equation in communication skill acquisition.

\subsection{Conceptual Framework}

This study adopted the following conceptual framework to illustrate the use of drawing as a pedagogical tool in the acquisition of communication skills in Early Years' Education in Kenya. 


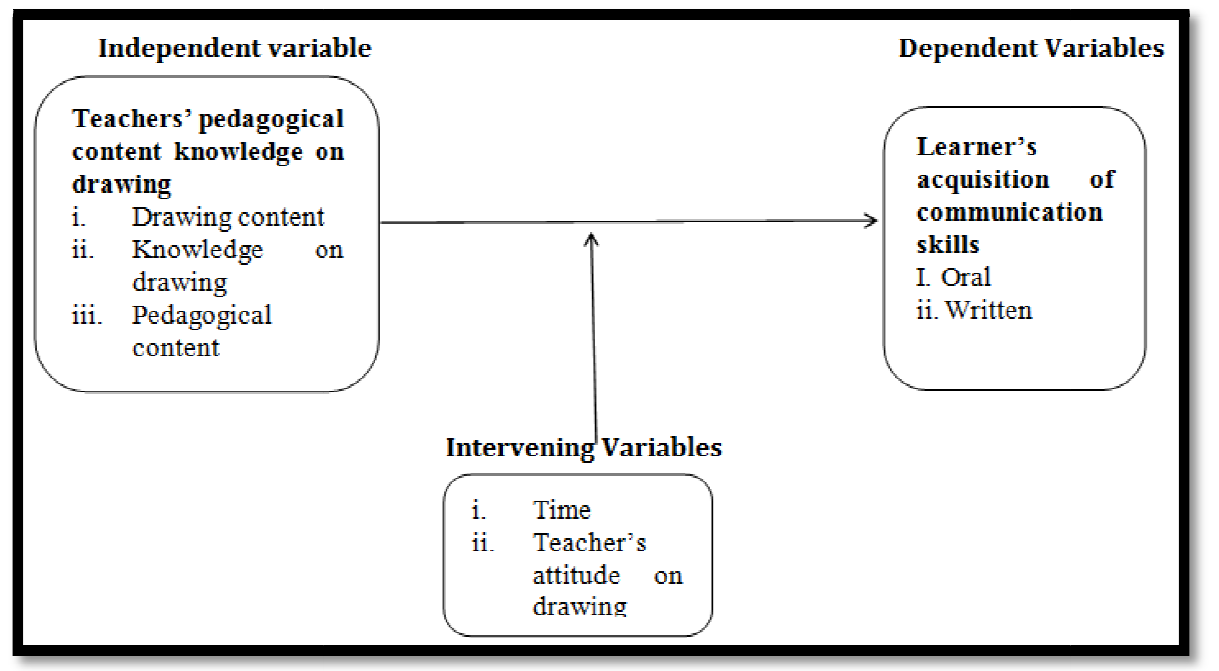

Figure 1: Conceptual Frameworks

Source: Author: Betty Tonui (2021)

\section{Review of Literature}

\subsection{Pedagogical Content Knowledge and Assessment in Drawing}

Pedagogical content knowledge includes curriculum topics to learn, the conceptions students bring to the learning of these concepts, teaching strategies tailored to the teaching situation. To teach according to the Early Childhood curriculum, teachers need to understand subjects matter deeply and flexibly so that they can help the learners map their ideas, relate one idea to the other and re-direct their thinking to create an effective learning process. Teachers need to see how ideas connect across fields of learning and everyday life. Therefore, teaching standards that demonstrate differences in teaching expectations to content knowledge, knowledge of general pedagogy and pedagogical content should be enhanced, (NBTS, 1998). The scarcity of research on content teaching in a classroom as a pressing issue in teacher education has received special focus in the United States as well as in other countries like Britain, Netherlands, Australia, South Africa and Kenya as well.

The answer to the critical question on teachers' pedagogical content and use of drawing in the acquisition of communication skills, clearly tell us that, teaching matters as well as the teachers' learning experiences. Research has proven that to improve the quality of teaching and learning in creative art-drawing, professional development develops the expertise.

Freir, (2018) aver that many teachers use assessments to identify learning dissimilarities among learners and to inform instructional planning and processes. In drawing activities, the intended purpose will determine what sort of assessment is most appropriate. Sato (2014) disagrees and argues that there is much learned from the experience in other educational settings about the uses, misuses, and unintended consequences of testing than just in a drawing. However, he believes drawing allows teachers to test the learners' feelings and ideas because this will enable the teacher to know where the learner is in the learning process and to plan appropriate activities to enhance the learning outcome. Nunan\& Lamb, (1996) has sustains that drawing is a tool that a teacher can use to nurture the learning skills which includes; communication expression and thus help learners to closely observe the world around them, recording and expressing what they observed and using that as a basis for further inquiry, thus enhancing communication skill acquisition, therefore, this study sought to explore the teachers' pedagogical content knowledge on drawing in the acquisition of communication skills in Early Years Education in Kenya.

Narrow research has been conducted in the areas of teacher pedagogical content knowledge of ECDE teachers and these have shown that teacher's pedagogical content knowledge is often squeaky and insufficient to provide the instructional opportunities needed for learners to successfully learn the preschool (Ball, 1998, 2003, Ball \& Bass, 2000; Fuller, 1996, Mewborn, 2001). Comparatively few studies have concentrated on the content knowledge of ECDE teachers on content learning areas, perhaps because of the belief that content knowledge may not be a problem at the ECDE level because of the teachers' specialized knowledge in ECDE curriculum areas (Ball et al., 2001). However, the available research, while limited, has served to reveal the misconception of this assumption (Ball et. al., 2001). At the secondary level, studies have considered teachers' content knowledge and pedagogical content knowledge in the areas of slope (Stump, 1997; Sherin, 2002) and functions (Even, 1993; Llinares, 2000; Sherin, 2002). Nathan \&Koedinger (2000) studied teachers' perceptions of algebraic reasoning. This exposes a big gap at the ECDE level to explore the pedagogical content knowledge on the use of drawing in the acquisition of communication skills in Early Years Education in Kenya.

Figure 2 is an illustration of a pot in which the teacher's beliefs have an influence on the learning outcome of the learner. 


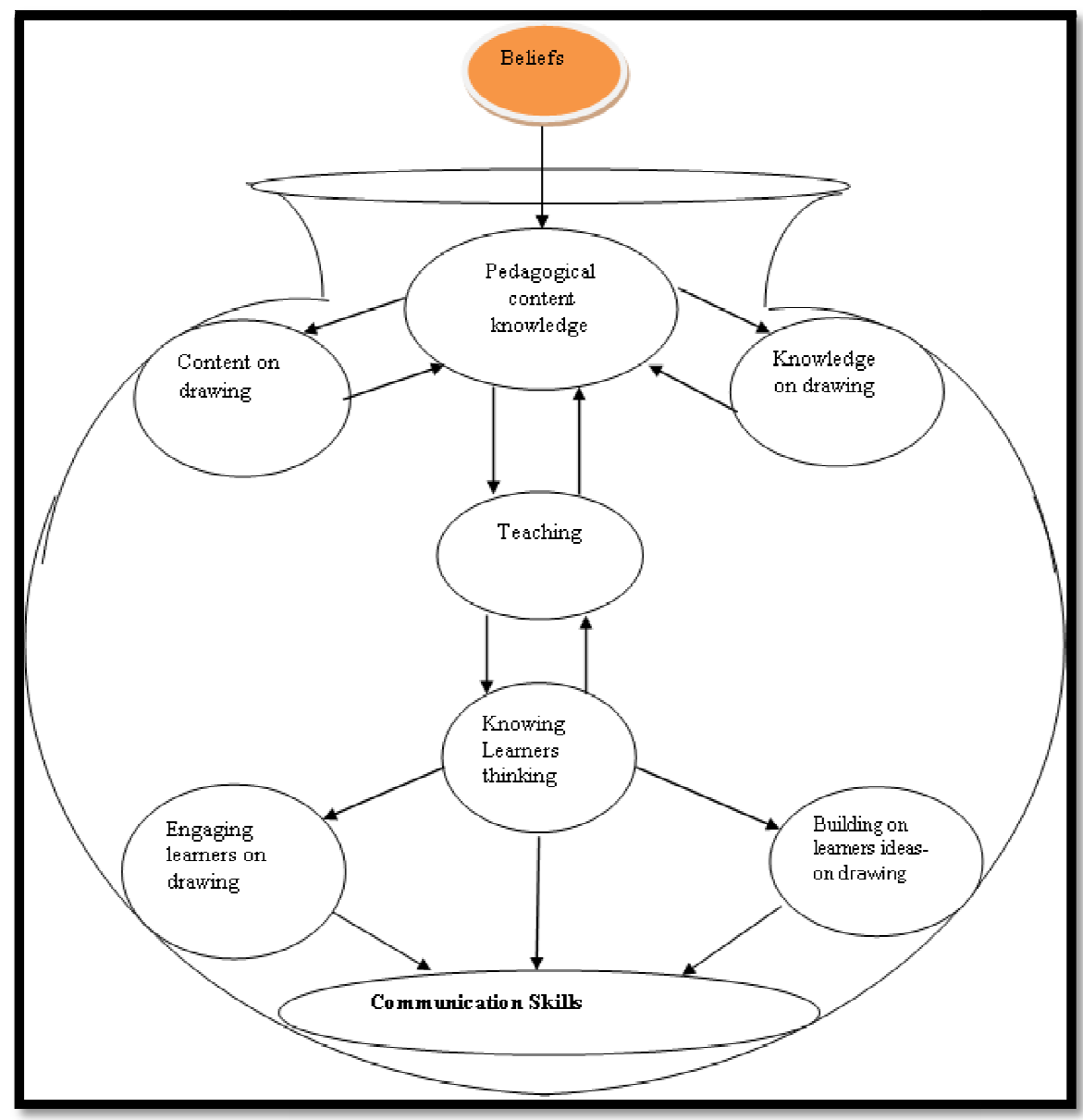

Figure 2: Teachers' Pedagogical Content Knowledge on Drawing Source: Author: Betty Tonui(2021)

There are other factors that come into play for the learning to be actualized include the pedagogical content knowledge on the activity area the teacher has to have, which includes the curriculum content as well as the knowledge on the subject and the methods used for effective teaching and learning processes on the subject. There has to be an interaction and interrelationship between the pedagogical content knowledge and the teaching, which in turn has to help the teacher understand the learner well. The teacher needs to understand the learners' state to plan appropriate achievable activities for them, which are engaging and building on their ideas as well. All these factors contribute to the learners' academic as well as communication skill development. This is illustrated in a pot above.

\subsection{Research Methodology}

\subsubsection{Research Design}

The researcher adopted a successive explanatory research design. A successive explanatory research design centers around clarifying the parts of a study in an itemized way whereby, giving subtitles where a modest quantity of data exists for a specific thought at the top of the priority list of the researcher, (Creswell et al 2014).

\subsubsection{Philosophical Paradigm}

This study embraces a logical perspective in its philosophical worldview to assess the utilization of drawing as an instructive tool in the acquisition of communication skills in early year's education in Kenya. The pragmatist approach was used to guide this study. The pragmatic choice gives room for mixed-methods to deal with the design of the research, both qualitative and quantitative methodologies.

\subsubsection{Research Method and Study Area}

Mixed approach was used in this study. In this study, the majority views were produced quantitatively while the in-depth perspectives on the study was done qualitatively and this research was carried out in Nandi County, Kenya

\subsubsection{Target Population}

There is a total of 805 public and 402 private ECDE schools/centers in Nandi County and target six (6) ECDE Sub County program officers, one per Sub County, 1,201 ECDE teachers from both public and private schools, 53, 276 Pp2 class from both public and private schools as shown in table 1. 


\begin{tabular}{|c|c|c|c|c|}
\hline Sub County & Schools & $\begin{array}{l}\text { ECDE Sub County } \\
\text { Program Officers }\end{array}$ & ECDE Teachers & Pp2 Class \\
\hline A & 218 & 1 & 218 & 9183 \\
\hline B & 220 & 1 & 220 & 10531 \\
\hline C & 227 & 1 & 227 & 7555 \\
\hline D & 167 & 1 & 167 & 111124 \\
\hline E & 124 & 1 & 124 & 8965 \\
\hline F & 245 & 1 & 245 & 6486 \\
\hline Total & 1201 & 6 & 1201 & 53,276 \\
\hline
\end{tabular}

Table 1: Target Population

Source: Nandi County Government Department of Education (2019)

\subsubsection{Sampling and Sampling Techniques}

The study sampled EYE 300 schools and 300 teachers were picked using simple random sampling and sample size of Pp2 class. After collecting drawings of Pp2 class, a non-Proportional purposive sample size was used to pick the samples. As shown in table 2.

\begin{tabular}{|c|c|c|c|c|}
\hline $\begin{array}{c}\text { Sampling } \\
\text { Techniques }\end{array}$ & \multicolumn{2}{|c|}{$\begin{array}{l}\text { Stratification \&Simple } \\
\text { Random Sampling }\end{array}$} & \multirow{3}{*}{$\begin{array}{c}\begin{array}{c}\text { Purposive Sampling- } \\
\text { Census }\end{array} \\
\begin{array}{c}\text { ECDE Programme } \\
\text { Officers }\end{array}\end{array}$} & \multirow{3}{*}{$\begin{array}{c}\begin{array}{c}\text { Simple Random } \\
\text { Sampling }\end{array} \\
\text { ECDE Teachers }\end{array}$} \\
\hline Stratification & & & & \\
\hline Sub County & Schools & PP2 Drawings & & \\
\hline A & 55 & 1 & 1 & 54 \\
\hline B & 55 & 1 & 1 & 55 \\
\hline $\bar{\beta}$ & 56 & 1 & 1 & 57 \\
\hline$\beta$ & 41 & 1 & 1 & 42 \\
\hline D & 31 & 1 & 1 & 31 \\
\hline 師 & 62 & 1 & 1 & 61 \\
\hline T要al & 300 & 6 & 6 & 300 \\
\hline
\end{tabular}

Table 2: Sample Size

The study interviews and EY learners' drawings to participate in the study. Therefore, 15 teachers ultimately participated in the interviews and $6 \mathrm{E}$ 害 learners' drawings included in the study.

\subsection{Data Generation Instruments}

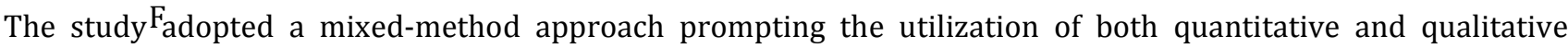
methodologies in data generation. The primary data generation instruments incorporated a questionnaire and an interviews schedule for both the teachers and Ministry of Education Programme officers.

\section{Findings and Discussions}

The study sought to explore the Teacher's Pedagogical Content Knowledge on Drawingin the acquisition of Communication skills in Early Years Education. To capture teachers pedagogical content knowledge on drawing, the researcher measured the following construct: Pre- service training generation. The preparation on drawing pedagogy

\subsection{Teachers'Pedagogical Content Knowledge on Drawing}

The study used three research instruments to generate data for the benefit of the objective. The questionnaire was answered by the EYE teachers. The interviews were done with teachers of EYE and Programme officers. The researcher used statements in a Likert scale that required teachers to respond in terms ofSA- Strongly agree,A-Agree, UN-Undecided, D- Disagree and SDStrongly Disagree. The results are indicated in table below: 


\begin{tabular}{|c|c|c|c|c|c|c|c|c|}
\hline $\begin{array}{c}\text { Teacher's Pedagogical Content } \\
\text { Knowledge on Drawing }\end{array}$ & & SD & D & UN & A & $\mathbf{S A}$ & Mean & Sd \\
\hline \multirow{2}{*}{$\begin{array}{l}\text { Drawing content knowledge was part of } \\
\text { my training in ECDE }\end{array}$} & $\mathrm{F}$ & 22 & 2 & 9 & 72 & 130 & 4.22 & 1.19 \\
\hline & $\%$ & 9.4 & .9 & 3.8 & 30.6 & 55.3 & & \\
\hline \multirow{2}{*}{$\begin{array}{c}\text { My classroom drawing decision is } \\
\text { determined to a large extent by the depth } \\
\text { of my pedagogical content knowledge on } \\
\text { drawing, }\end{array}$} & $\mathrm{F}$ & 49 & 2 & 2 & 118 & 64 & 3.62 & 1.43 \\
\hline & $\%$ & 20.9 & .9 & .9 & 50.2 & 27.2 & & \\
\hline \multirow{2}{*}{$\begin{array}{l}\text { I do not prefer using drawing in my } \\
\text { classroom activities because I am not } \\
\text { sure if I am doing it correctly }\end{array}$} & $\mathrm{F}$ & 24 & 2 & 2 & 31 & 176 & 4.42 & 1.24 \\
\hline & $\%$ & 10.2 & .9 & .9 & 13.2 & 74.9 & & \\
\hline \multirow{2}{*}{$\begin{array}{c}\text { There is sufficient content in Creative art } \\
\text { activity area to help learners acquire } \\
\text { communication skills }\end{array}$} & $\mathrm{F}$ & 169 & 18 & 2 & 18 & 28 & 1.87 & 1.47 \\
\hline & $\%$ & $\begin{array}{l}71.9 \\
11.9 \\
\end{array}$ & 7.7 & .9 & 7.7 & 11.9 & & \\
\hline \multirow{2}{*}{$\begin{array}{l}\text { I interpret and give meaning to the } \\
\text { learner's drawings }\end{array}$} & $\mathrm{F}$ & 38 & 8 & 20 & 100 & 69 & 3.66 & 1.36 \\
\hline & $\%$ & 16.2 & 3.4 & 8.5 & 42.6 & 29.4 & & \\
\hline \multirow{2}{*}{$\begin{array}{l}\text { I prefer to use drawing to support } \\
\text { classroom learning activities because } \\
\text { learners enjoy drawing effortlessly }\end{array}$} & $\mathrm{F}$ & 25 & 8 & 21 & 96 & 85 & 3.89 & 1.24 \\
\hline & $\%$ & 10.6 & 3.4 & 8.9 & 40.9 & 36.2 & & \\
\hline \multirow{2}{*}{$\begin{array}{l}\text { I use the EYE curriculum design to } \\
\text { develop the schemes of work and plan } \\
\text { drawing activities lessons always }\end{array}$} & $F$ & 122 & 2 & 56 & 44 & 11 & 2.23 & 1.37 \\
\hline & $\%$ & 51.9 & .9 & 23.8 & 18.7 & 4.7 & & \\
\hline \multirow{2}{*}{$\begin{array}{l}\text { Learners cannot acquire Communication } \\
\text { skill any better with the use of drawing } \\
\text { activities }\end{array}$} & $\mathrm{F}$ & 69 & 2 & 18 & 85 & 61 & 3.29 & 1.59 \\
\hline & $\%$ & 29.4 & .9 & 7.7 & 36.2 & 26.0 & & \\
\hline Valid N & \multicolumn{8}{|c|}{235} \\
\hline
\end{tabular}

Table 3: Teachers' Pedagogical Content Knowledge on Drawing on the Acquisition of Communication Skills

All the teachers who responded to questionnaires were 235. Table 4.6 indicates that 22(9.4\%) of the respondents strongly disagreed and 2(9\%) disagreed that drawing content knowledge was part of what the teachers had during teacher training. However, $9(3.8 \%)$ of the respondents were undecided about that statement but $72(30.6 \%)$ agreed and a majority of $130(55.3 \%)$ of the respondents strongly agreed with the statement that drawing content knowledge was part of teachers' training as shown by (Mean=4.22, $\mathrm{SD}=1.19$ ). This implies that teacher development is a necessary part of attaining and maintaining drawing pedagogy that requires enhancing the learners' Communication skill acquisition.

The findings from the Sub County Program Officers interviews on the training and experience, acknowledged that EYE teachers should have basic professional knowledge in early childhood education that consists of interpretation and meaning making of children's drawings. Programme officers during interview had this to say:

'Most of the EYE teachers in my sub-county are trained in ECDE. The least with a proficiency in ECDE and the highest with a degree in Early childhood Education. Majority of these teachers are elderly and have been teaching for more than 13 years, so I can say they are experienced in teaching Early childhood education' Po participant serial no. $b$.

"Some few of my EYE teachers have Bachelor of Education (ECDE) degree and understand what children draw. They make good drawings on charts and display for the children. When children draw, their drawings are also pasted on the classroom wall". Po Participant serial no. $d$

The findings from an Open-ended question in the questionnaire by EYE teachers on their training and experience had this to say,

I did early childhood in my training and have a diploma certificate in ECDE and we had a subject called Creative Art. Drawing was one of the subjects that we covered' EYET Participant serial no. 6

'In as much as we have gained teaching experience, there is still a big need for continuous in-service training for teachers to enable us to cope with the changes in education system'EYET Participant serial no. 3

"There is a need for more in-service workshops for EYE teachers especially for drawing activities. This will enhance the teachers' knowledge in drawing activities on top of the knowledge gained from their earlier training"YET

Participant serial no 1

Results indicate that a large proportion of teachers are trained in EYE in which one of their learning subjects' contents is Creative art in which drawing is embedded. The excerpts suggest that, that the majority of teachers are trained in early childhood development and pedagogical content knowledge on Creative art. This implied that EYE schools had qualified teachers and that the aspects sought in this study was familiar to them. It also implied that the respondents could read, comprehend and respond to the questions in the questionnaire. The findings concur with Basheka (2010) and World Bank, (2000) who argued that, if education level relates to professionalism, then one can assume that the information provided is valid and reliable. Wyse, (2002) qualifies that the more training and professional qualification a teacher possesses, the better the teacher's teaching experience and outcome.

The excerpt further proposes that educators need more supplemental classes so as to build confidence in use of drawing. The response by EYE Teachers upheld empirical studies by Hattie, (2003) and Rockoff, (2004) that an educator who has been educating at a specific evaluation level for over five years was emphatically and altogether connected with 
increased pupil's achievement. This is significant on the grounds that it gives the fundamental knowledge, abilities and confidence required. The findings further concurred with Law (2016) who analysed what educators think about the content Related Experience (CRE) and how confident they can become in its pedagogy. The study uncovered that there is a connection between educator's pedagogical content knowledge on drawing with what students realize in their drawing exercises, which if objectively planned for can improve Communication skills acquisition. This study further saw that, more supplemental classes are expected to prepare educators on the utilization of drawing exercises EYE classrooms as indicated by a high 67(28.6\%) of teachers not trained in ECDE as shown in table 4.2. The findings concurred with Barnett and Hodson (2014) who clarify further the significance of a teachers' pedagogical content knowledge that, it is the teachers' understanding and changes of subject matter content with regards to encouraging learners into their learning. The findings could additionally be in accordance with (Loughran et al., 2012) that, it is a thought established in beliefs that education requires more than conveying subjects' content to learners and that learning is something beyond retaining data for later accurate regurgitation.

Similarly, the statement on the association between classroom drawing decision and teachers' pedagogical content knowledge was agreed on by the respondents with a $(M=3.62, S D=1.43)$. This implies that teachers' pedagogical content knowledge on drawing plays a critical role in the acquisition of Communication skill making this an essential component of the acquisition of communication skills by EYE learners. The results concur with Johnston and Goettsch (2013) who examined aspects of the knowledge base that experienced English as a second language (ESL) teachers use drawing to illustrate in their teaching, primarily in explaining grammar and other language points.

From the interview responses by EYE teachers on factors that influence drawing pedagogical content activities a teacher chooses to actively engage learners in, they acknowledged that EYE teachers' decision making in drawing activities is influenced by factors critical to use of drawing. These factors include; the drawing content, drawing knowledge and drawing pedagogy to mention a few. The EYE teachers had this to say:

'I am not so sure if I am engaging learners in the way they should. I just tell the learners 'Just draw me what you like'. Sometimes, I copy a picture and tell learners to copy exactly like what I have given to them 'EYETparticipant serial no. 9

'I did Creative Art when I was in college. I used to draw pictures though they were not good enough but I draw them anyway. I think I did not do enough practice to give me confidence in use of drawing' EYET participant serial no. 6

The knowledge on drawing I received in my training is enough to help me interpret the learners' drawings and make meaning out of it' EYET participant serial no. 2

I like drawing activities. I understand what learners draw. We practiced lots of drawing in my training and I find it easy to use illustrations in activity areas. Learners like drawings and understand concepts faster when I use them. EYET participantserial no. 10

I use drawing a lot in my class to help learners understand the lessons. I think, this is because we were taught well in our training. And also, I find my learners happy when I give them drawing activities' EYET participant serial no. 5

These excerpts suggest that, the content and knowledge of drawing has a significant role on what a teacher does in class on the subject content. When a teacher has sufficient information on an activity area, then using that information for a specific purpose will bring out the desired outcome. In this case, when a teacher has adequate content knowledge on drawing, using drawing will bring out the Communication skill desired. This includes representations, that most useful in teaching creative art (drawing), (Bell et al., 2013). Teachers should have the ability to create connections between Creative art-drawing content areas, knowledge and pedagogy. Teachers' pedagogical content knowledge is important to the improvement of teaching and learning processes.

On teachers' preference using drawing in the classroom activities, they admitted that, the knowledge teachers have on use of drawing is not adequate to engage learners in drawing activities. The statement had $24(10.2 \%)$ and $2(0.9 \%)$ of the respondents strongly disagreeing and disagreeing respectively whereas $2(0.9 \%)$ of the respondents were undecided while $31(13.2 \%)$ agreed and the majority $176(74.9 \%)$ strongly agreed with the statement. The majority of the respondents agreed that teachers prefer using drawing in their classroom activities (Mean=4.429, (SD=1.24). This implies that teachers prefer to use drawing in classroom activities. The results concur with Claxton and Carr (2004) who examined what teachers know about Drawing Related Experience (DRE) and how confident they are in their knowledge. Their results indicated that teachers were very confident in their pedagogical content knowledge of DRE. This study implies that targeted teacher development in teaching creative art is a necessary part of attaining and maintaining drawing knowledge required.

Majority $169(71.9 \%)$ of the respondents and 18(7.7) strongly disagreed and disagreed respectively that there's sufficient content on drawing to enhance communication skill acquisition on EYE curriculum design 02(.9\%) were undecided, 18(7.7\%) agreed and 28(11.9\%) strongly disagreed with the statement. Respondents however disagreed with the statement that there's sufficient content on drawing to enhance communication skill acquisition on EYE curriculum design (Mean=1.87, $\mathrm{SD}=1.47$ ). This implies that the EYE teachers suggest that drawing content in the curriculum design is not adequate to enhance communication skill acquisition in EYE. These findings are in agreement with (Jwan, 2016) who argues that content knowledge in a subject plays a critical role in the classroom activities and in the teachers' creative thinking process.

Another $38(16.2 \%)$ of the respondents strongly disagreed, $8(3.4 \%)$ disagreed, $20(8.5 \%)$ were undecided, the Majority $100(42.6 \%)$ agreed and $69(29.4 \%)$ strongly agreed that they can interpret and give meaning to learner's drawings. Respondents thus agreed that teachers can interpret and give meaning to learners' drawings (Mean=3.66, $\mathrm{SD}=1.24)$. 
Likewise, $25(10.6 \%)$ of the respondents strongly disagreed and $8(3.4 \%)$ disagreed that teachers prefer to use drawing to support learning in classroom activities because it is enjoyable and learners engage in it effortlessly. 21(8.9\%) of the respondents were undecided on the statement. The Majority $96(40.9 \%)$ and $85(36.2 \%)$ of the respondents agreed and strongly agreed. This statement was generally agreed on by respondents (Mean=2.23, SD=1.37). This implies that the respondents agreed with the statement and that teachers prefer drawing to support learning in classroom activities because it is enjoyable and learners engage in it effortlessly.

Consequently, 2(0.9\%) of the respondents strongly agreed that teachers do not use the EYE curriculum design in planning for drawing activities, 11(4.7\%) of the respondents only agreed with the statement but 44(18.7\%) were undecided. This statement on teachers uses the EYE curriculum design in planning for drawing activities was however disagreed and strongly disagreed by 56(23.8\%) and the Majority 122 (51.9\%) of the respondents respectively. The respondents disagreed with the statement that teachers do not use the EYE curriculum design for drawing lessons (Mean=3.89, $\mathrm{SD}=1.24)$. This implies that teachers are found to be able to plan and prepare drawing activities lesson that can enhance communication skill acquisition.

Lastly, 18(7.7\%) of the respondents strongly disagreed that learners can acquire Communication skill any better with the use of drawing, 2(0.9\%) disagreed, 61(26\%) were undecided, the Majority 85(36.2\%) agreed and 69(29.426\%) strongly agreed with the statement. Respondents agreed on the statement that teachers think learners can acquire communication skills better with the use of drawing (Mean=3.29, SD=1.59). This implies that learners can acquire Communication skills better with the use of drawing EYE.

The researcher was also interested in finding out through an open -ended questionnaire if the EYE teachers see any possibility of engaging learners in drawing activities that can enhance communication skill acquisition. The study finding revealed that majority of teachers strongly agreed on the possibilities of using drawing activities in their classroom to enhance communication skill acquisition. The EYE teachers through an excerpt had this to say; '...if planned for and organized well drawing can be used to help children tell stories of their drawings. This way can enhance communication skill acquisition' EYET participant serial no. 12

'If a teacher plans to achieve a specific objective, then he or she will arrange the teaching learning resources and environment as well as the lesson activities to achieve the objective' EYET participant serial no. 12

'... the new curriculum has acquisition of communication skills in other activity areas but with the use of drawing, Communication skill can be more achievable' EYET participant serial no. 5

The excerpts and the open-ended questionnaire responses suggested that the Majority 218(92.8\%) of teachers see the possibilities of communication skill acquisition if objectively planned for. This is further supported by the comments as summarized by the table below.

\begin{tabular}{|c|c|c|c|}
\hline Thematic Area & Questions Asked & Themes & $\begin{array}{c}\text { Sub- themes (Responses) } \\
\mathrm{N}=15(100 \%)\end{array}$ \\
\hline $\begin{array}{l}\text { Teachers' } \\
\text { pedagogical } \\
\text { Content } \\
\text { Knowledge on } \\
\text { drawing }\end{array}$ & $\begin{array}{l}\text { 1. What does } \\
\text { drawing mean? } \\
\text { 2. Was drawing } \\
\text { content part of your } \\
\text { drawing content } \\
\text { training? } \\
\text { 3. Is there sufficient } \\
\text { content in Creative } \\
\text { art activity area to } \\
\text { help learners acquire } \\
\text { Communication } \\
\text { skills? } \\
\text { 4. What challenges } \\
\text { do you face in } \\
\text { drawing activities? } \\
\text { 5. What } \\
\text { Communication } \\
\text { Skills can be acquired } \\
\text { by use of drawing in } \\
\text { EYE? }\end{array}$ & $\begin{array}{l}\text { Meaning of } \\
\text { drawing } \\
\text { Training on } \\
\text { drawing } \\
\text { Content of } \\
\text { drawing activities } \\
\text { in Curriculum } \\
\text { design } \\
\\
\text { Challenges } \\
\text { teachers face in } \\
\text { use of drawing } \\
\text { activities } \\
\text { Suggestions by } \\
\text { identifying } \\
\text { Communication } \\
\text { skills acquired } \\
\text { through drawing }\end{array}$ & $\begin{array}{l}15(100 \%) \text { - all teachers were } \\
\text { able to explain the meaning of } \\
\text { the drawing } \\
15(100 \%) \text { - all teachers } \\
\text { indicated that training was part } \\
\text { of their subject content. } \\
\text { 15(100\%)-all teachers } \\
\text { complained of insufficient } \\
\text { content in Creative Art activity } \\
\text { areas for enhancing } \\
\text { communication skill acquisition. } \\
\text {-Lack of sufficient time } \\
\text {-Inadequate resources } \\
\text {-Overcrowding and insufficient } \\
\text { physical facilities. } \\
\text {-Lack of in-service training. } \\
\text { - Negative teacher attitude } \\
\text { towards drawing } \\
\text {-Lack of teacher commitment. } \\
\text {-Oral } \\
\text {-Listening } \\
\text {-Writing } \\
\text {-Gestural }\end{array}$ \\
\hline
\end{tabular}

Table 4: Themes and Sub- Themes Elicited on Teachers Content Knowledge on Drawing in the Acquisition of Communication Skills Are Summarized 
The results suggests that, all EYE teachers interviewed were able to explain the meaning of drawing and that all teachers indicated that training was part of their subject content in their training curriculum. Teachers agreed further and complained of inadequate drawing content allocated in EYE Curriculum design. On the question on challenges, all teachers complained of inefficient resources that included; lack of sufficient time, inadequate writing resources, overcrowding, insufficient physical facilities, lack of refresher courses, negative attitude towards drawing by the teachers and lack of teacher commitment to drawing among others.

The researcher further delved with the suggestions teachers would give on Communication Skills that can be acquired by use of drawing in EYE. Most teachers 13(86\%) agreed that Oral Communication skill would highly be enhanced by drawing activities preceded by listening skill, writing and gestural skill development respectively.

\subsection{Regression Analysis for Teacher's Pedagogical Content Knowledge}

The study examined teacher's pedagogical content knowledge on drawing in the acquisition of learner's Oral Communication skills in Early Years' Education. Table 4.2 presents the results of regression analysis.

\begin{tabular}{|c|c|c|c|}
\hline $\mathbf{R}$ & R Square & $\begin{array}{c}\text { Adjusted R } \\
\text { Square }\end{array}$ & Std. Error of the Estimate \\
\hline .415 & .172 & .168 & .47591 \\
\hline
\end{tabular}

Table 5: Regression Model Summary

a. Predictors: (Constant), Teacher's Pedagogical Content Knowledge on Drawing

b. Dependent Variable:Acquisition of Communication Skills in Early Years Education

Model summary gives the coefficient of determination (R2) which shows the extent of the difference in the dependent variable (Communication skill) that is predictable from the independent variable (Teachers' pedagogical content knowledge on drawing) and relationship coefficient (R) shows the level of relationship between the Communication skill (dependent variable) and Teachers' educational substance information on drawing (independent variable). The results presented in Table 4.5 present the fitness of the model used of the regression model in clarifying the study phenomena.

The teacher's pedagogical content knowledge on drawing variables was found to be good in influencing the acquisition of Communication skills in Early Years Education in Kenya. This is upheld by the coefficient of determination otherwise called the $\mathrm{R}$ square of $17.2 \%$. This implies the Teacher's pedagogical content knowledge on drawing clarifies $17.2 \%$ of the variations in the dependent variable. The outcomes further suggest that the model applied to interface the relationship of the factors was satisfactory. Adjusted R2 is a changed form of R2 that has been adjusted for the quantity of predictors in the model by less than chance. The adjusted R2 of which was adjusted slightly lower than the R2 value was a definite indicator of the connection between the independent and the dependent variable since it is sensitive to the addition of unessential variables. The adjusted R2 shows that the model explains $16.8 \%$ of the adjustments in the acquisition of Communication skills in Early Years Education in Kenya.

\subsection{Assessing the Fit of the Regression Model}

The study examined whether the multi-regression model was a good fit for the data. Analysis of Variance (ANOVA) was conducted to see whether the Acquisition of Communication Skills in Early Years Education can be anticipated without depending on Teachers' pedagogical content knowledge on drawing. The results of the Analysis of Variance (ANOVA) are shown in Table 4.3.

\begin{tabular}{|c|c|c|c|c|c|}
\hline & Sum of Squares & Df & Mean Square & F & Sig \\
\hline Regression & 10.951 & 1 & 10.951 & 48.451 & $.000 \mathrm{a}$ \\
\hline Residual & 52.773 & 233 & .226 & & \\
\hline Total & 63.724 & 234 & & & \\
\hline
\end{tabular}

Table 6: Results of ANOVA

a.Predictors: (Constant), Teacher's Pedagogical Content Knowledge on Drawing

b.Dependent Variable:Acquisition of Communication Skills in Early Years Education

Table 6 gives the results on the analysis of variance (ANOVA). The outcome shows that the overall model was statistically significant as supported by a p estimation of 0.000 which is lesser than the degree of significance critical $p$ estimation of 0.05 . Further, the outcome suggests that the Teacher's pedagogical content knowledge on drawing is a good predictor of Acquisition of Communication Skills in Early Years Education. This was upheld by an F statistic of 48.451 and the revealed $p$ value $(0.000)$ which was not exactly the conventional probability of 0.05 degree of significance.

\subsection{Regression Coefficients}

Regression of coefficients results in Table 4.7 shows that educators' pedagogical content knowledge has a significance and positive influence on acquisition of communication skills in Early Years Education $(\beta=0.422, p=0.000)$. 


\begin{tabular}{|c|c|c|c|c|c|c|}
\hline \multirow{2}{*}{\multicolumn{2}{|c|}{ Model }} & \multicolumn{2}{|c|}{$\begin{array}{l}\text { Unstandardized } \\
\text { Coefficients }\end{array}$} & \multirow{2}{*}{$\begin{array}{c}\text { Standardized } \\
\text { Coefficients } \\
\text { Beta } \\
\end{array}$} & \multirow[t]{2}{*}{$\mathbf{T}$} & \multirow[t]{2}{*}{ Sig. } \\
\hline & & $\mathrm{B}$ & Std. Error & & & \\
\hline \multirow[t]{2}{*}{1} & (Constant) & .683 & .244 & & 2.799 & .000 \\
\hline & $\begin{array}{c}\text { Teacher's pedagogical } \\
\text { content knowledge on } \\
\text { drawing }\end{array}$ & .422 & .061 & .415 & 6.953 & .000 \\
\hline
\end{tabular}

Table 7: Regression Analysis Coefficients

The optimal model was;

$\mathrm{Y}=0.683+4.22 \mathrm{X} 1$

Where:

Y represents Acquisition of Communication Skills in Early Years Education, dependent variable

$\mathrm{X} 1$ represents Teacher's pedagogical content knowledge on drawing

From the regression model computed in Table 4.4, the research hypotheses were tested using a level of significance of 0.05. The research aimed to test the hypothesis with an intention of failing to reject or rejecting the relationship between independent and the dependent variable.

- H01:Teachers' pedagogical content knowledge on drawing has no significant influence in the acquisition of communication skills in Early Years Education. The regression results in Table 4.4 indicate that there is a significant relationship between the teachers' pedagogical content knowledge on drawing activities and use in the acquisition of communication skills in Early years Education with a beta coefficient of 0.422 and $p=0.000$. The study rejected the hypothesis.

\section{Conclusion Recommendation}

\subsection{Conclusions}

In light of the outline of the findings the following conclusions were made; it was seen that, teachers' pedagogical content knowledge on drawing enhances the acquisition of communication skills in early years Education. Teachers' pedagogical content knowledge on drawing has been believed to influence the learner's communication processes. During drawing, learners are continually thinking or feeling something that influences the decision of what they choose to draw, the examples they use, and the narrative they attempt to express. This study hence, presumed that teachers can utilize drawing as a means for gaining a language of communication with the EYE learners.

\subsection{Recommendations}

Out of this research, the researcher recommends that teachers' need to embrace the use of drawing with a focus in the acquisition of communication skills in Early Years Education. This is because of the vital role drawing has in the acquisition of communication skills in early years education. The researcher noted that, for example, a few teachers' put less accentuation on learner's drawings. Teachers' regularly use drawing activities to involve learner's during free playtime as asserted by Anning (2015). The researcher consequently suggests that learner's drawing ought to be valued in terms of its instructive result on learners' self-expressions. Accordingly, in view of the findings, it is suggested that drawing as a pedagogical tool ought to be given prominence in all EYE learning encounters as it improves communication skills acquisition.

\section{References}

i. Adams, E. (2006). Drawing attractions: a comprehensive store of ideas, reports, explanations and strategies for using drawing as a means of engaging people with heritage and can be used by educators in a wide range of environments and cultural settings. Campaign for Drawing.

ii. Barnett, J., \&Hodson, D. (2014). Pedagogical context knowledge: Toward a fuller understanding of what good science teachers know. Science Education, 85(4), 426-453.

iii. Barrett, M. D., Beaumont, A., \& Jennett, M. (1985). Some children do sometimes do what they have been told to do: Task demands and verbal instructions in children's drawings. In N. H. Freeman \& M. V. Cox (Eds.), Visual order: The nature and development of pictorial representation (pp. 176-187). Cambridge: Cambridge University Press. doi:10.2466/PMS.70.2.663 [Crossref], [Google Scholar]

iv. Cohen, L., \&Manion, L. (2017). K. (Keith RB Morrison. Research methods in education.

v. Deguara, J. (2015). Meaning-making in young children's drawings (Doctoral dissertation, University of Sheffield).

vi. Even, R. (1993). Subject-matter knowledge and pedagogical content knowledge: Prospective secondary teachers and the function concept. Journal for research in mathematics education, 94-116.

vii. Foks-Appelman, T. L. (2012). Draw Me a Picture: The Meaning of Children's Drawings and Play from the Perspective of the Analytical Psychology. Foxapscriptus.

viii. Gichuba, C., \&Opatsa, R. N. R.(2010). General methods of teaching young children and material development.

ix. Kenya Institute of Curriculum Development, (KICD) (2017). Basic Education Curriculum Framework. Published by KICD, Kenya

x. Kothari, C. R., \& Gang (2014). Research methodology: Methods and techniques. 
xi. Merriam, S. B. (2015). Qualitative research: Designing, implementing, and publishing a study. In Handbook of research on scholarly publishing and research methods (pp. 125-140). IGI Global.

xii. Mewborn, D. (2001). Teachers content knowledge, teacher education, and their effects on the preparation of elementary teachers in the United States. Mathematics Teacher Education and Development, 3(1), 28-36.

xiii. Papandreou, M. (2014). Communicating and thinking through drawing activity in early childhood. Journal of Research in Childhood Education, 28(1), 85-100.

xiv. Pelto, P. J. (2015). What is so new about mixed methods? Qualitative Health Research, 25(6), $734-745$.

xv. Twoli, N. W., Maundu, J. N., Muindi, D. M., Kiio, M., \&Kithinji, C. T. (2007). Instructional methods in education.

xvi. Uwezo. (2016). Are our children learning (2016)? Uwezo Kenya sixth learning assessment report, December 2016.

xvii. Yin, R. K. (2014). Case study research: Design and methods (applied social research methods). Thousand Oaks, CA: Sage publications. 